\title{
Genotypic variation in the expression of guarding behavior and the role of guards in the defensive response of honey bee colonies
}

\author{
Miguel E. Arechavaleta-Velasco*, Greg J. Hunt \\ Department of Entomology, Purdue University, West Lafayette, IN 47907, USA
}

(Received 13 March 2002; revised 27 August 2002; accepted 17 February 2003)

\begin{abstract}
This study was conducted to identify genotypic variation in the expression of guarding behavior between defensive and gentle backcross colonies and to determine the role of guards in the defensive response of a colony. No differences were found between backcross types for the average time that a bee behaves as a guard. Differences were found between backcross types and between colonies for the number of bees that guard for at least one day and for at least two days. Variation between colonies for these two variables was partially genetic in origin. A small proportion of the bees that stung during stinging assays were guards, and only a small proportion of the guards stung. Positive correlations were found between the number of stings and both the number of guards in the colony and the proportion of guards that stung in relation to the total number of guards in the colony. Colonies responded with fewer stings when guards were removed in comparison to when guards were present in the colonies.
\end{abstract}

guarding behavior / stinging behavior / defensive behavior / Apis mellifera

\section{INTRODUCTION}

Honey bee colony defense is divided into two distinct behaviors, guarding and stinging. A guard bee is a worker that patrols the entrance of the hive in search of bees, insects, animals or any other object that approaches the colony (Breed et al., 1990). Guards are very active and quickly approach and inspect bees that alight on the landing board before they are allowed to enter the hive. Inspection involves antennation of the newly arrived bee, which leads to the recognition of nest mates and the rejection of non-nest mates. Guard bees often adopt a characteristic stance when they are not moving; they stand with their forelegs off the ground and with their antennae pointing forward. Guards typically hold their wings away from their body, as if they were preparing to fly (Moore et al., 1987). Responders, also called stingers, are bees that respond to major disturbances to the colony by flying out, stinging and sometimes pursuing intruders (Breed et al., 1990).

Maschwitz (1964) reported that when bees standing at the entrance of the hive were disturbed, they released alarm pheromone to recruit other bees from the interior of the hive that were ready to sting. Breed et al. (1988) showed that guards are responsive to isopentyl acetate, the principal active compound found in the honey bee alarm pheromone.

\footnotetext{
* Corresponding author: arechava@ stat.purdue.edu Present address: Department of Statistics, Purdue University, 150N University Street, Mathematical Science Building, West Lafayette, IN 47907-2067, USA.
} 
A significant correlation was found between the time that a bee guards and the number of bees in a colony that react to alarm pheromone. This correlation may establish a link between guards and responders via alarm pheromone recruitment (Maschwitz, 1964; Moore et al., 1987).

Guarding behavior is influenced by the environment (Butler and Free, 1952; Ribbands, 1954; Breed and Rogers, 1991). Downs and Ratnieks (2000) found that guarding behavior, measured by number of guards and by the number of fights observed at the entrance of the hive, changes during a period of time depending on the robbing pressure from other colonies as a consequence of the presence or absence of nectar in the field.

Robinson and Page (1988) established that guard bees are a genetically non-random sample of the subfamilies in the colony, showing that the genotype of the workers influences the probability that a bee behaves as a guard in the colony. Breed et al. (1990) found that guards and responders are behaviorally differentiated groups of bees, and suggested that guarding behavior evolved as a mechanism to defend the colony against nest robbing by other invertebrates while mass stinging behavior of responders evolved as a result of vertebrate predation. In another study, Breed and Rogers (1991) using colonies classified either as high defensive or as low defensive, found that the expression of guarding behavior is influenced by colony genotype and is affected by the colony environment. Guards from the highly defensive colonies guarded for a longer period of time than the guards from the low defensive colonies.

Studies have been conducted to understand the genetics of stinging behavior (Stort, 1974, 1975a, b, c; Collins et al., 1982, 1988; Guzmán-Novoa and Page, 1993, 1994; Hunt et al., 1998; Guzmán-Novoa et al., 2002). But little is known about the genetics of guarding behavior, the other component of honey bee colony defensive behavior. The objectives of this study were to (1) identify genotypic variation in the expression of guarding behavior of defensive and gentle backcrossed honey bee colonies and (2) determine the role that guard bees played in the defensive response of a colony.

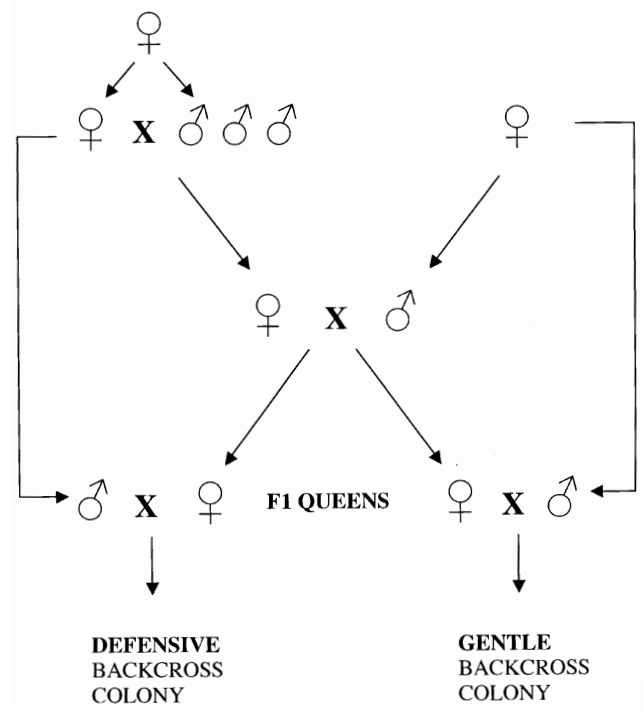

Figure 1. Mating scheme used to produce colonies composed of backcross workers derived from a defensive colony and a gentle colony.

\section{MATERIALS AND METHODS}

\subsection{Experimental colonies}

Two honey bee (Apis mellifera $\mathrm{L}$.) colonies were used for this study, one classified as high defensive and one classified as low defensive. The two colonies were selected among 90 colonies based on their relative defensiveness measured by a rating method (Arechavaleta and Guzmán-Novoa, 1996; Hunt et al., 1998; Guzmán-Novoa et al., 2002). A queen was reared from the defensive colony and was artificially inseminated with the semen of three of her brothers. From this queen a daughter queen was reared and inseminated with the semen of a drone from the gentle colony. From this daughter queen, twelve hybrid queens were reared and divided into two groups. Six queens were singledrone artificially inseminated with drones from the defensive colony and six queens were single-drone artificially inseminated with drones of the gentle colony in order to produce two types of colonies composed of backcross workers (Fig. 1).

Each queen was introduced into a small colony made of three frames of brood, two frames of honey and approximately $1.5 \mathrm{~kg}$ of bees. The colonies were kept in single deep Langstroth hives in the 
same apiary. All colonies were managed the same way for a period of 60 days prior to the beginning of the experiments to allow time for workers in the colony to be replaced by daughters of the inseminated queens. During this period, three queens of the gentle backcross were lost, so the experiments were conducted with six defensive and three gentle backcross colonies. All colonies were approximately the same size measured by the number of frames covered with bees and the number of frames with brood. A Kruskall-Wallis test was performed on data collected at the beginning and at then end of the experiments (Steel and Torrie, 1988) to compare these parameters between colonies.

\subsection{Expression of guarding behavior}

\subsubsection{Duration of guarding}

Each colony was observed for a period of 40 minutes on the same day and all the bees performing guarding behavior at the entrance of the hive were marked on their thorax with a dot of enamel paint. Different colors were used for each hive. The number of bees marked from each colony was recorded. The colonies were observed for a period of 30 minutes each day for the next 14 days and the number of marked bees that continued guarding in each colony was recorded for each day. Two repetitions of this procedure were performed. The average number of days that a bee guarded for each backcross type was estimated and a $t$-test was performed to compare the means of the two types of backcross colonies.

\subsubsection{Number of guards}

In a second set of experiments each colony was observed for a period of 30 minutes and the guards observed at the entrance of each hive were counted and marked with enamel paint. Twenty-four hours later, marked bees that continued to guard were counted to determine the number of guards that performed the behavior for at least two days. This procedure was repeated on five different occasions, allowing a $24 \mathrm{~h}$ period between each repetition. To identify genotypic differences in the number of bees that guarded for at least one day and for at least two days between backcross types and between colonies, data were analyzed using an analysis of variance under a nested design.

To identify genotypic and environmental effects in the expression of guarding behavior, an analysis of variance components was performed under a complete random design counting for the effect of the queen that headed each colony (Van Vleck, 1993; Lynch and Walsh, 1998). The genotypic variance was estimated from the variation due to the queen effect and was estimated using the intraclass correlation. The environmental variance was estimated by the variance of the error in the model (Falconer, 1989; Kearsy and Pooni, 1996). The queens that headed the backcrossed colonies shared the same queen mother and drone father. Consequently, the queens were super-sisters that had an average genetic relationship of at least 0.75 . Therefore, the variation between the colonies will be genetic in origin under the same environmental conditions.

\subsection{Role of guards during colony stinging response}

Another set of experiments was performed using the same nine colonies to determine the role that guard bees play in the defensive response of a colony. The colonies were observed for a period of 30 minutes and all the bees performing guarding behavior were marked with a dot of enamel paint on their thorax. Different colors were used for each of the colonies. The number of guards marked from each colony was recorded.

Four hours after the guards of the last colony were marked, the defensive behavior of each colony was tested using a stinging behavior assay (Villa, 1988; Guzmán-Novoa and Page, 1993). In this test, a $10 \times 10 \mathrm{~cm}$ piece of black suede impregnated with $5 \mu \mathrm{L}$ of $98 \%$ isopentyl acetate (Sigma ${ }^{\circledR}$ Cat. No. 11,267-4) and attached to the end of a one meter stick was waved by hand in a rhythmic way approximately $10 \mathrm{~cm}$ from the entrance of the hive. The bees were allowed to sting the patch for 60 seconds after the first sting. If no stinging occurred, the test was terminated after 120 seconds. After this period, the piece of suede was introduced into a plastic bag. Five repetitions of the marking and testing process were performed with a $48 \mathrm{~h}$ period between repetitions.

The number of stings in the piece of suede was recorded in order to measure the defensiveness of each colony. The number of marked bees that stung the patch was recorded in order to estimate the proportion of guards in relation to the total number of bees that stung. A ratio between the marked guards and those that responded by stinging the piece of suede was calculated.

A $t$-test to compare the means of the two types of backcross colonies, and an analysis of variance under a complete random design were performed to look for differences between colonies for the variables: total number of stings, proportion of guards that stung in relation to the total number of bees that stung and the proportion of guards that stung in relation to the total number of guards marked. 
A correlation analysis was performed between the number of stings in the suede patch and the number of guards marked, the proportion of guards that stung in relation to the total number of bees that stung and the proportion of guards that stung in relation to the total number of guards marked.

\subsection{Influence of guards on the stinging response of honey bee colonies}

To analyze the effect that guards have on the defensive response of the colonies, the stinging behavior of the experimental colonies was tested with and without removal of guards. Each colony was observed for a period of 30 minutes and all guard bees at the entrance of the hive were removed from the colony using a pair of tweezers. Four hours after the guards of the last colony were removed, the stinging behavior of the colonies was tested using the flag test as described previously. Forty-eight hours later, the stinging behavior of the colonies was tested without removing guards. Three repetitions of this procedure were performed. A paired $t$-test was used to look for differences in the number of stings deposited in the flag by the bees when guards were present in the colony and when guards were removed.

\section{RESULTS}

\subsection{Experimental colonies}

No differences were found between colonies during the time of the experiments for the number of frames with brood $(\mathrm{H}=9.21$; $\mathrm{df}=$ $8 ; P>0.05)$ and for the number of frames covered with bees $(\mathrm{H}=11.04 ; \mathrm{df}=8 ; P>0.05)$.

\subsection{Expression of guarding behavior}

\subsubsection{Duration of guarding}

No differences were found between the two types of backcross colonies for the average number of days that a bee performed guarding behavior in the colony $(t=0.46$; $\mathrm{df}=1201$; $P=0.65$ ). The guards of the defensive backcross colonies performed the behavior for 1.98 days on average while the guards of the gentle backcross guarded for a mean period of 1.92 days. Of the total number of bees marked $(\mathrm{n}=1203)$ in all the colonies, $71.99 \%$ guarded for only one day, $7.75 \%$ guarded for two days, and less than $1 \%$ guarded for eight days or more (Fig. 2).

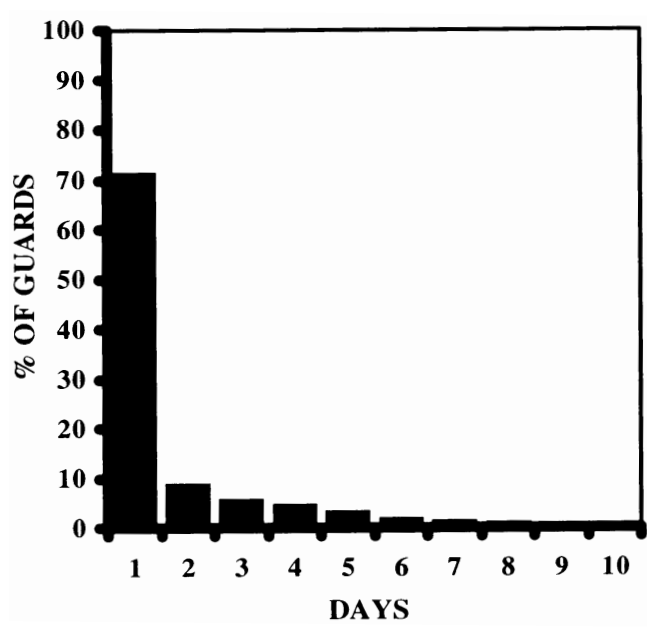

Figure 2. Frequency distribution of marked guards $(n=1203)$ for the number of days that an individual bee performed guarding behavior.

\subsubsection{Number of guards}

Differences were found for the number of bees that guarded for at least one day between backcross types $(\mathrm{F}=11.43 ; \mathrm{df}=1,36 ; P<$ $0.005)$ and between colonies $(\mathrm{F}=5.37 ; \mathrm{df}=7$, $36 ; P<0.001)$. The mean number of guards observed per day in the colonies of the defensive backcross was $112.8 \pm 32.0$ and the mean of the gentle backcrossed colonies was $84.8 \pm 38.5$ (Fig. 3).

More bees guarded for at least two days in the defensive backcrossed colonies than in the gentle backcrossed colonies. $(\mathrm{F}=6.91$; $\mathrm{df}=$ $1,36 ; P<0.05)$. The mean number of bees that guarded for at least two days were $22.83 \pm 9.5$ and $16.33 \pm 9.9$ for the defensive backcrossed and the gentle backcrossed colonies respectively (Fig. 4). There were also differences between the colonies nested into backcross type for this variable $(\mathrm{F}=4.24$; $\mathrm{df}=7,36$; $P<0.005)$.

The analysis of variance components showed that $50.6 \%$ of the variation for the number of bees that guarded for at least one day and $41.7 \%$ of the variation for the number of bees that guarded for at least two days was related to the queen effect. The variation due to the queen effect is an estimator of the genotypic variance, which includes additive, 


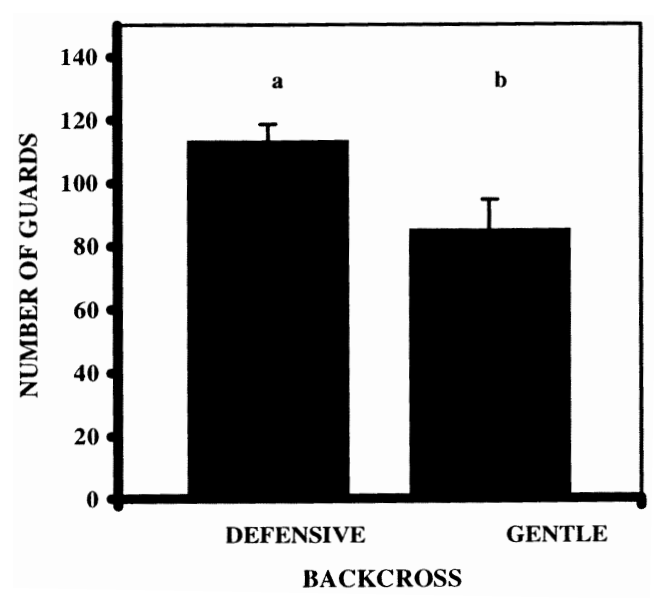

Figure 3. Average number of bees performing guarding behavior for at least one day. Defensive backcross colonies have significantly more bees guarding than gentle backcross colonies $(\mathrm{F}=11.43$; df $=1,36 ; P<0.005)$. Different letters indicate differences between the means of the two types of backcross colonies, based on ANOVA and LSM tests.

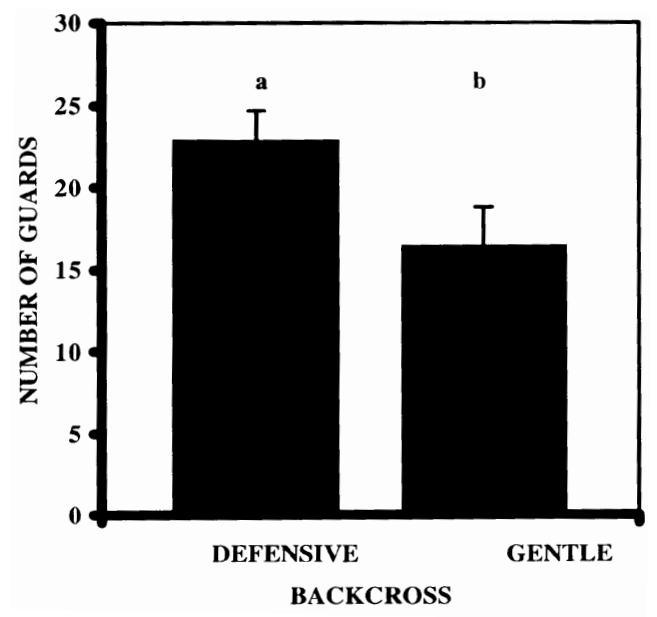

Figure 4. Average number of bees performing guarding behavior for at least two days. Defensive backcross colonies have significantly more bees guarding than gentle backcross colonies $(\mathrm{F}=6.91$; $\mathrm{df}=1,36 ; P<0.05)$. Different letters indicate differences between the means of the two types of backcross colonies, based on ANOVA and LSM tests.

dominant and epistatic components, under the assumption that the colony environments are equal. The variance attributed to the error in
Table I. Genotypic and environmental variance components for the number of bees performing guarding behavior for at least one day and at least two days. Figures in parentheses are the proportion of the phenotypic variance explained by the variance source.

\begin{tabular}{lcc}
\hline $\begin{array}{l}\text { Variance } \\
\text { source }\end{array}$ & $\begin{array}{c}\text { One day guards } \\
\text { estimator }\end{array}$ & $\begin{array}{c}\text { Two day guards } \\
\text { estimator }\end{array}$ \\
\hline Genotypic & $703.27(50.6 \%)$ & $43.65(41.7 \%)$ \\
Environmental & $686.01(49.4 \%)$ & $61.13(58.3 \%)$ \\
Phenotypic & $1389.27(100 \%)$ & $104.78(100 \%)$ \\
\hline
\end{tabular}

the model is an estimator of the environmental variance (Tab. I).

\subsection{Role of guards during colony defensive response}

No differences were found between the two types of backcross in the number of bees that stung the suede flag $(t=0.58$; df $=43$; $P>0.05)$, but there were significant differences between the colonies $(\mathrm{F}=2.45$; $\mathrm{df}=$ $8,36 ; P<0.05)$. The mean number of bees that stung from the defensive backcross was $96.5 \pm$ 67.5 and the mean for the gentle backcross was $108.8 \pm 65.2$.

No differences were found for the proportion of guards that stung in relation to the total number of bees that stung between backcrosses $(t=0.88 ; \mathrm{df}=43 ; P>0.05)$ or between colonies $(\mathrm{F}=1.61 ; \mathrm{df}=8,36 ; P>0.05)$. The average proportion of guards that stung of the total number of bees that stung was $2.3 \%$ for the defensive backcross and $1.4 \%$ for the gentle backcross colonies. For the proportion of guards that stung in relation to the total number of guards marked, no differences were found between backcross types $(t=0.61$; $\mathrm{df}=43 ; P>0.05)$, but differences were found between colonies for this variable $(\mathrm{F}=2.26$; $\mathrm{df}=8,36 ; P<0.05)$. The mean proportion for the defensive backcross colonies was $2.5 \%$ and the mean proportion for the gentle backcross colonies was $1.9 \%$.

Positive correlations were found between the number of stings that the bees deposited in the suede flag with the number of guards marked at the entrance of the hives $(\mathrm{r}=0.41$; $\mathrm{n}=45 ; P<0.01)$ and between the number of stings in the flag with the proportion of guards 
Table II. Correlation (r) coefficients of the number of bees that stung during defensive behavior tests with the total number of guards in the colony, with the proportion of guards that stung in relation to the total number of guards and with the proportion of guards that stung in relation to the total number of bees that stung.

\begin{tabular}{lccc}
\hline Characteristic & n & r & $\boldsymbol{P}$ \\
\hline $\begin{array}{l}\text { Total number of guards } \\
\begin{array}{l}\text { Proportion of guards that stung } \\
\text { in relation to total number of } \\
\text { guards }\end{array}\end{array}$ & 45 & 0.41 & 0.0058 \\
$\begin{array}{l}\text { Proportion of guards that stung } \\
\text { in relation to total number of } \\
\text { bees that stung }\end{array}$ & 45 & 0.46 & 0.0015 \\
\hline
\end{tabular}

that stung in relation to the total number of guards marked $(\mathrm{r}=0.46 ; \mathrm{n}=45 ; P<0.001)$. But no correlation was found between the number of bees that stung and the proportion of guards that stung in relation to the total number of bees that stung $(\mathrm{r}=0.28 ; \mathrm{n}=45$; $P>0.05)$ (Tab. II).

\subsection{Influence of guards on the defensive response of honey bee colonies}

Significant differences $(t=3.74$; df $=26$; $P<0.001)$ were found in the number of bees that stung when guards were removed four hours before the test compared to tests in which the guards were not removed. The average number of bees that stung was 85.3 when the guards were removed and 127.5 when the guards where not removed (Fig. 5).

\section{DISCUSSION}

The average number of days that a bee guarded in this study was similar to that of other studies (Moore et al., 1987; Breed et al., 1988). The bees in this study guarded 1.9 days on average after having been marked. In our study no differences were found between the defensive backcross and the gentle backcross colonies for the mean number of days that a bee guards. Breed and Rogers (1991) found differences between two groups of colonies, one classified as high defensive and one as low defensive.

The method used in this study to determine the time that a bee behaves as a guard could

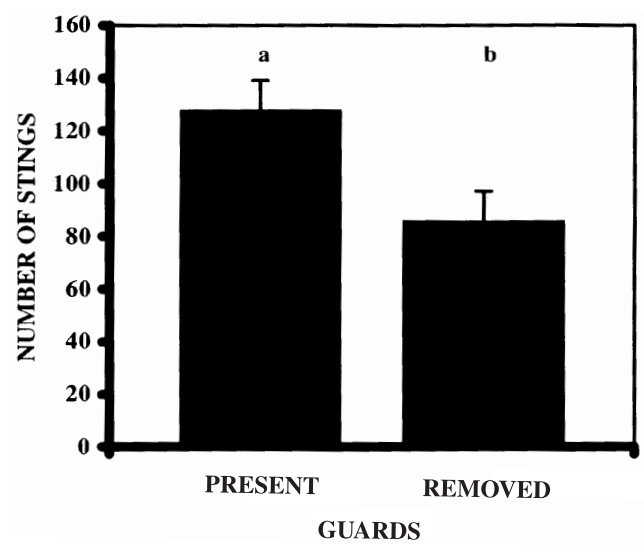

Figure 5. Average number of bees that stung with or without removing guards from the colonies. Colonies deposited a higher number of stingers during the defensive tests when guards were present in the colonies than when guards were removed $(t=3.74 ; \mathrm{df}=26 ; P<0.001)$. Different letters indicate differences between the means of the colonies based on a paired $t$-test.

under-estimate the number of days that a bee guarded. However, results of this and other studies (Moore et al., 1987; Breed and Rogers, 1991) indicate that most bees perform guarding behavior for only one day and that the average number of days that a bee guards is close to two days. The differences detected in the present study for the number of bees that guarded for at least one day and for the number of bees that guarded for at least two days between backcross types and between colonies indicate that the genotype of a colony influences the expression of guarding behavior. Defensive backcross colonies had more bees guarding than gentle backcross colonies, even tough they were approximately of the same size.

The differences observed in the number of guards were due to the genetic composition of the colonies. The analysis of variance components indicated that part of the phenotypic variation in the number of bees that guarded for at least one day and for the bees that guarded at least two days was attributed to genotypic effects and also indicates that environmental effects are important. Other studies also have indicated that the environment had an important effect on the expression of guarding behavior (Butler and Free, 1952; Ribbands, 
1954; Breed and Rogers, 1991; Downs and Ratnieks, 2000). The estimator for the genotypic variance calculated in this study could be over-estimated due to the small sample size and due to the fact that the mating scheme used to produce the backcross colonies include mating of individuals that were genetically related.

High variation was found among the experimental colonies in the number of stings deposited during the defensive tests, as was found in previous studies (Stort, 1974, 1975a, b, c; Collins et al., 1982, 1988; Villa, 1988; Guzmán-Novoa and Page, 1993, 1994). But no differences were detected in the numbers of stings deposited by both types of backcross colonies. These results suggest that some degree of dominance exists in the expression of stinging behavior. Other studies also reported genetic dominance for colony stinging responses (Stort 1974, 1975a; GuzmánNovoa and Page, 1993, 1994; Guzmán-Novoa et al., 2002).

The stinging response of the colonies showed a positive correlation with the number of guards observed at the entrance of the hives. High defensive colonies tended to have more bees guarding than colonies that had a lower defensive response. Based on the genetic structure of the experimental colonies these results indicate that a genetic correlation exists between these two traits and that genes that influence stinging behavior also influence guarding behavior. Recent studies found that a quantitative trait locus (sting-1) that influences stinging behavior, that was mapped as a colony trait (Hunt et al., 1998) also influences the expression of guarding behavior in individual honey bees (Guzmán-Novoa et al., 2002; Arechavaleta-Velasco et al., 2003).

Less than three percent of the bees that stung the flag were guards indicating that guards and stingers played different roles during the defensive response of a colony. Breed et al. (1990) reported that guards and stingers were two different groups of bees, but our results also showed that some of the guards flew out and respond by stinging when a colony was disturbed. A relatively small proportion of the guards stung, but a positive correlation was found between the proportion of the guards that stung and the total number of bees that stung the flag.
The colonies showed a lower defensive response when bees performing guarding behavior were removed from the colony. The variation in the defensive level of the colonies with or without guards suggests that guards play an active role in the defensive response of a honey bee colony. The fact that the number of guards in the colony and the stinging response of a colony were positively correlated is also evidence that guards influence the defensive response of a colony. It is not clear exactly what role the guards play. Guards in our study were extremely agitated and active on the landing board when colonies were disturbed during the flag tests. One hypothesis is that guards recruit other bees to react to a disturbance, possibly through alarm pheromone. One of the major functions of alarm pheromone is to recruit bees from the interior of the hives, increase flight activity and enhance response to moving objects (Maschwitz, 1964; Wager and Breed, 2000). Some of the guards in our study flew out and stung. Guards could provide both visual and chemical cues to stingers in order to recruit them to respond to an object during honey bee colony defense. These results show that guards are involved in the defensive response of a colony and that guards participate in such a way that their presence, their number, and the proportion of them that react by stinging influence the intensity of the stinging response of a colony.

\section{ACKNOWLEDGMENTS}

This work was funded with grants from NIH R29 GM54850 and USDA 2001-35302-10137. We thank Ernesto Guzmán-Novoa for critical review of this manuscript. We thank Tom Glenn for his help with the instrumental inseminations and also to Damon Hall and Christine Emore for their assistance in various ways.

Résumé - Variation génotypique du comportement des gardiennes et leur rôle dans les réactions de défense des colonies d'abeilles domestiques. Cette étude avait pour but d'identifier la variation génotypique du comportement des gardiennes entre colonies rétrocroisées d'abeilles (Apis mellifera L.) agressives et d'abeilles douces et de déterminer le rôle joué par les gardiennes dans la réaction de défense de la colonie. Les colonies rétrocroisées ont été produites en inséminant artificiellement avec un seul mâle des reines F1. Les mâles provenaient soit d'une colonie agressive, soit 
d'une colonie douce. On a utilisé 6 colonies rétrocroisées avec la colonie source agressive et trois avec la colonie source douce (Fig. 1). Aucune différence n'a été trouvée entre les colonies rétrocroisées en ce qui concerne le nombre moyen de jours durant lequel une abeille était gardienne. La plupart des abeilles n'étaient gardiennes qu'un seul jour (Fig. 2). Des différences significatives ont été trouvées entre colonies rétrocroisées d'une part et entre colonies du même type d'autre part en ce qui concerne le nombre d'abeilles qui étaient gardiennes au moins un jour (Fig. 3) et au moins deux jours (Fig. 4). L'analyse des composantes de la variance montre qu'une partie de la variation est d'origine génétique (Tab. I). Le nombre d'abeilles qui ont piqué le morceau de cuir lors du test de défense est positivement corrélé au nombre de gardiennes à l'entrée des ruches et à la proportion de gardiennes qui piquaient (Tab. II). Moins d'abeilles piquaient lorsque les gardiennes étaient retirées des colonies $4 \mathrm{~h}$ avant les tests de piqûre (Fig. 5). Nos résultats montrent des effets du génotype dans la variation entre colonies pour le nombre d'abeilles faisant office de gardiennes durant au moins 1 et $2 \mathrm{j}$. La réaction de défense des colonies montre une corrélation positive avec le nombre de gardiennes dans les ruches. Ces résultats indiquent l'existence d'une corrélation génétique pour ces deux caractères. Une proportion relativement faible de gardiennes a piqué, mais une corrélation positive a été trouvée entre la proportion de gardiennes qui piquaient et le nombre total d'abeilles qui piquaient. Les colonies ont présenté une moindre réaction de défense lorsque les gardiennes avaient été retirées de la colonie. Ceci prouve que les gardiennes sont impliquées dans la réaction de défense de la colonie et qu'elles y participent par le fait que leur présence, leur nombre et la proportion d'entre elles qui réagissent par piqûre influencent l'intensité de la réaction de défense de la colonie.

Apis mellifera / comportement de défense / comportement de piqûre / gardienne

Zusammenfassung - Genotypische Variationen im Verhalten von Wächtern und ihre Rolle bei Verteidigungsreaktionen von Völkern der Honigbienen. Es wurde die genotypische Variation im Verhalten der Wächter zwischen verteidigungsstarken und auf Sanftmut gezüchteten Linien der Honigbienen (Apis mellifera L.) sowie die Rolle der Wächterbienen bei Verteidigungsreaktionen untersucht. Die Völker wurden durch Rückkreuzung von Königinnen mit einem Drohn durch instrumentelle Besamung erzeugt. Die Drohnen stammten von F1 Königinnen aus einem verteidigungsstarken Volk. Sechs Völker wurden mit verteidigungsstarkem und drei mit sanftem Ausgangsmaterial rückgekreuzt (Abb. 1). Die durchschnittliche Dauer des Wachens wurde zwischen den Rückkreuzungen verglichen. Die Anzahl der Wächterbienen wurde über mindestens einen Tag bzw. über zwei Tage bei einem rückgekreuzten Volk und innerhalb der Völker verglichen.

Um die Rolle der Wächterbienen bei der Verteidigungsreaktion zu bestimmen, wurde das Verteidigungsverhalten der Bienenvölker mit einer "Probe für Stechverhalten" getestet. Zur Zeit des Tests wurde die Anzahl der Wächter pro Volk, die Anzahl der stechenden Wächter und die Gesamtzahl der stechenden Bienen pro Volk gezählt. Zusätzlich wurde das Stechverhalten der Völker mit und ohne Wächterbienen getestet. Es ergaben sich keine Unterschiede zwischen den Rückkreuzungen bezüglich der mittleren Anzahl von Tagen, die eine Bienen ihren Wächterdienst versieht. Die meisten Bienen sind nur für einen Tag Wächter (Abb. 2). Signifikante Unterscheide ergaben sich zwischen den Rückkreuzungen und den Völkern in der Anzahl der Bienen, die mindestens einen Tag (Abb. 3) bzw. mindestens zwei Tage Wächter waren (Abb. 4). Die Analyse der variablen Komponenten zeigte, dass ein Teil der Variation auf genetischem Ursprung beruhte (Tab. I). Die Anzahl der stechenden Bienen korrelierte positiv mit der Anzahl der Wächter beim Stockeingang und mit dem Anteil der stechenden Wächter (Tab. II). Vier Stunden nach Entfernung der Wächter stachen weniger Bienen als beim Test mit Wächtern (Abb. 5). Unsere Ergebnisse zeigen einen genotypischen Effekt in der Variation zwischen Völkern bei der Anzahl der Bienen, die mindestens für ein oder zwei Tage Wächterdienst versahen. Die Verteidigungsreaktion der Völker zeigte eine positive Korrelation zu der Anzahl der Wächter in den Völkern. Daraus ergibt sich eine genetische Korrelation zwischen diesen beiden Merkmale. Ein relativ kleiner Teil der Wächter stach, aber es wurde eine positive Korrelation zwischen dem Anteil der stechenden Wächter und der Gesamtzahl der stechenden Bienen gefunden. Völker zeigten eine geringere Verteidigungsreaktion, wenn die Wächter entfernt waren. Diese Ergebnisse zeigen, dass die Wächter in der Verteidigungsreaktion beteiligt sind und dass Wächter dadurch partizipieren, dass ihre Präsenz, ihre Anzahl und ihr Anteil an stechenden Bienen die Intensität des Stechverhaltens eines Volkes beeinflussen.

\section{Verhalten von Wächterbienen / Stechverhalten / Verteidigungsverhalten / Apis mellifera}

\section{REFERENCES}

Arechavaleta-Velasco M.E., Guzmán-Novoa E. (1996) Evaluación de la Defensividad de las Colonias de Abejas Apis mellifera L. por medio del Método de Apreciación, [Evaluation of honey bee Apis mellifera L.; defensiveness with a rating method.], in: Proc. IX Seminario Americano de Apicultura, Veracruz, Ver., Mexico, SAGAR, 3 p. 
Arechavaleta-Velasco M.E., Hunt G.J., Emore C. (2003) Quantitative trait loci that influence the expression of guarding and stinging behaviors of individual honey bees, Behav. Genet. 33, 357364.

Breed M.D., Rogers K.B. (1991) The behavioral genetics of colony defense in honeybees: genetic variability for guarding behavior, Behav. Genet. 21, 295-303.

Breed M.D., Rogers K.B., Hunley J.A., Moore A.J. (1988) A correlation between guard behaviour and defensive response in the honey bee, Apis mellifera, Anim. Behav. 37, 515-516.

Breed M.D., Robinson G.E., Page R.E. Jr. (1990) Division of labor during honey bee colony defense, Behav. Ecol. Sociobiol. 27, 395-401.

Butler C.G., Free J.B. (1952) The behavior of worker honeybees at the hive entrance, Behavior 4, 262292.

Collins A.M., Rinderer T.E., Harbo J.R., Bolten A.B. (1982) Colony defense by Africanized and European honey bees, Science 218, 72-74.

Collins A.M., Rinderer T.E., Tucker K.W. (1988) Colony defense of two honeybee types and their hybrids. I. Naturally mated queens, J. Apic. Res. 27, 137-140.

Downs S.G., Ratnieks F.L.W. (2000) Adaptive shifts in honey bee (Apis mellifera L.) guarding behavior support predictions of the acceptance threshold model, Behav. Ecol. 11, 326-333.

Falconer D.S. (1989) Introduction to quantitative genetics, Longman Scientific \& Technical.

Guzmán-Novoa E., Page R.E. Jr. (1993) Backcrossing Africanized honey bee queens to European drones reduces colony defensive behavior, Ann. Entomol. Soc. Am. 86, 352-355.

Guzmán-Novoa E., Page R.E. Jr. (1994) Genetic dominance and worker interactions affect honeybee colony defense, Behav. Ecol. 5, 91-97.

Guzmán-Novoa E., Hunt G.J., Uribe J.L., Smith C., Arechavaleta-Velasco M.E. (2002) Confirmation of QTL effects and evidence of genetic dominance of honey bee defensive behavior: Results of colony and individual behavioral assays, Behav. Genet. 32, 95-102.

Hunt G.J., Guzmán-Novoa E., Fondrk M.K., Page R.E. Jr. (1998) Quantitative trait loci for honey bee stinging behavior and body size, Genetics 148, 1203-1213.
Kearsy M.J., Pooni H.S. (1996) The genetical analysis of quantitative traits, Chapman \& Hall.

Lynch M., Walsh B. (1998) Genetics and analysis of quantitative traits, Sinauer Associates, Inc.

Maschwitz U.W. (1964) Alarm substances and alarm behaviour in social hymenoptera, Nature 204, 324-327.

Moore A.J., Breed M.D., Moor M.J. (1987) The guard honey bee: ontogeny and behavioural variability of workers performing a specialized task, Anim. Behav. 35, 1159-1157.

Ribbands C.R. (1954) The defense of the honeybee community, Proc. R. Soc. London B 142, 514 524.

Robinson G.E., Page R.E. Jr. (1988) Genetic determination of guarding and undertaking in honey-bee colonies, Nature 333, 356-358.

Steel R.G.D., Torrie J.H. (1988) Principles and procedures of statistics. A biometrial approach, McGraw-Hill, Inc.

Stort A.C. (1974) Genetic study of the aggressiveness of two subspecies of Apis mellifera in Brazil. I. Some test to measure aggressiveness, J. Apic. Res. 13, 33-38.

Stort A.C. (1975a) Genetic study of the aggressiveness of two subspecies of Apis mellifera in Brazil. II. Time at which the first sting reached the leather ball, J. Apic. Res. 14, 171-175.

Stort A.C. (1975b) Genetic study of the aggressiveness of two subspecies of Apis mellifera in Brazil. IV. Number of stings in the gloves of the observer, Behav. Genet. 5, 269-274.

Stort A.C. (1975c) Genetic study of the aggressiveness of two subspecies of Apis mellifera in Brazil. V. Number of stings in the leather ball, J. Kans. Entomol. Soc. 48, 381-387.

Van Vleck L.D. (1993) Selection index and introduction to mixed model methods, CRC Press.

Villa J.D. (1988) Defensive behavior of Africanized and European honeybees at two elevations in Colombia, J. Apic. Res. 27, 141-145.

Wager B.R., Breed M.D. (2000) Does honey bee sting alarm pheromone give orientation information to defensive bees?, Ann. Entomol. Soc. Am. 93, 1329-1332. 